\title{
Identification and molecular characterization of tryptophanase encoded by tna $A$ in Porphyromonas gingivalis
}

\author{
Yasuo Yoshida, ${ }^{1}$ Takako Sasaki, ${ }^{1}$ Shuntaro Ito, ${ }^{1,2}$ Haruki Tamura, ${ }^{1}$ \\ Kazushi Kunimatsu ${ }^{2}$ and Hirohisa Kato ${ }^{1}$ \\ ${ }^{1}$ Department of Dental Pharmacology, Iwate Medical University School of Dentistry, Morioka, Japan \\ ${ }^{2}$ Department of Periodontology, Iwate Medical University School of Dentistry, Morioka, Japan
}

Correspondence

Yasuo Yoshida

yasuoy@iwate-med.ac.jp

Received 11 September 2008

Revised 11 November 2008

Accepted 13 November 2008

\begin{abstract}
Indole produced via the $\beta$-elimination reaction of L-tryptophan by pyridoxal 5 '-phosphatedependent tryptophanase (EC 4.1.99.1) has recently been shown to be an extracellular and intercellular signalling molecule in bacteria, and controls bacterial biofilm formation and virulence factors. In the present study, we determined the molecular basis of indole production in the periodontopathogenic bacterium Porphyromonas gingivalis. A database search showed that the amino acid sequence deduced from pg1401 of $P$. gingivalis W83 is $45 \%$ identical with that from tnaA of Escherichia coli K-12, which encodes tryptophanase. Replacement of the pg1401 gene in the chromosomal DNA with the chloramphenicol-resistance gene abolished indole production. The production of indole was restored by the introduction of $p g 1401$, demonstrating that the gene is functionally equivalent to tnaA. However, RT-PCR and RNA ligase-mediated rapid amplification of cDNA ends analyses showed that, unlike $E$. coli tna $A, p g 1401$ is expressed alone in $P$. gingivalis and that the nucleotide sequence of the transcription start site is different, suggesting that the expression of $P$. gingivalis tna $A$ is controlled by a unique mechanism. Purified recombinant $P$. gingivalis tryptophanase exhibited the Michaelis-Menten kinetics values $K_{\mathrm{m}}=0.20 \pm 0.01 \mathrm{mM}$ and $k_{\text {cat }}=1.37 \pm 0.06 \mathrm{~s}^{-1}$ in potassium phosphate buffer, but in sodium phosphate buffer, the enzyme showed lower activity. However, the cation in the buffer, $\mathrm{K}^{+}$or $\mathrm{Na}^{+}$, did not appear to affect the quaternary structure of the enzyme or the binding of pyridoxal $5^{\prime}$ phosphate to the enzyme. The enzyme also degraded $S$-ethyl-L-cysteine and $S$-methyl-L-cysteine, but not L-alanine, L-serine or L-cysteine.
\end{abstract}

\section{INTRODUCTION}

Tryptophanase (tryptophan indole-lyase, EC 4.1.99.1) occurs in a wide variety of bacteria. The protein encoded by tnaA is a pyridoxal $5^{\prime}$-phosphate (PLP)-dependent enzyme that catalyses the $\beta$-elimination reaction of $\mathrm{L}$ tryptophan to yield indole, ammonium and pyruvate (Snell, 1975). Tryptophanases from Escherichia coli (Phillips, 1987; Watanabe \& Snell, 1977) and Proteus vulgaris (Zakomirdina et al., 2002) have also been reported to be associated with the in vitro $\beta$-elimination reactions of a wide range of natural and synthetic amino acids. E. coli tryptophanase functions as a tetramer of four $52.8 \mathrm{kDa}$ 471-residue subunits (Deeley \& Yanofsky, 1981; Kagamiyama et al., 1972), and although the dimeric form of the enzyme can be isolated (Raibaud \& Goldberg, 1976) or induced by cold (Erez et al., 1998), it is inactive. In the

Abbreviations: CRP, cAMP receptor protein; GST, glutathionine $S$ transferase; PLP, pyridoxal 5'-phosphate; RLM-RACE, RNA ligasemediated rapid amplification of cDNA ends. active form of $E$. coli tryptophanase, each subunit contains one molecule of PLP that forms a Schiff base with the side chain of Lys-270, but can be removed by dialysis to produce the apoform of the enzyme (Metzler et al., 1991). $\mathrm{K}^{+}$plays a role in stabilizing the oligomeric structure of tryptophanase, as cold dissociation of the enzyme has been shown to occur slowly in the presence of this cation (Erez et al., 1998), whereas $\mathrm{Na}^{+}$has been shown to inhibit the activity of the enzyme (Snell, 1975).

Indole is one of the malodorous oral volatile products, which include methyl mercaptan, hydrogen sulphide, skatole and cadaverine (Fosdick \& Piez, 1953; Kostelc et al., 1981; Claesson et al., 1990; Goldberg et al., 1994). Interestingly, the molecule was recently reported to decrease biofilm formation by $E$. coli, but to increase that by Pseudomonas spp. (Lee et al., 2007). The molecule also controls multidrug exporters (Hirakawa et al., 2005) and regulates the pathogenicity island in E. coli (Anyanful et al., 2005). Moreover, a relationship between the ability of Haemophilus influenzae strains to produce indole and cause 
certain infectious diseases, including meningitis, has been reported (Martin et al., 1998). Thus, indole is not only a malodorous product, but also an extracellular and intercellular signalling molecule.

Porphyromonas gingivalis is a Gram-negative, black-pigmented, asaccharolytic obligate anaerobe that has been implicated in the initiation and progression of periodontal disease (Lamont \& Jenkinson, 2000). This micro-organism is regarded as a secondary colonizer of oral biofilm (Kolenbrander et al., 2002), and its primary niche is the anaerobic environment of subgingival pockets (Lamont \& Jenkinson, 1998; Yoshida et al., 2003b). The production of methyl mercaptan from methionine by this microorganism has been demonstrated (Yoshimura et al., 2000), but most of the enzymes associated with the degradation of amino acids are unknown. As a first step in investigating the relationship between indole production and virulence in $P$. gingivalis, we characterized a gene homologue of tnaA and its purified recombinant product.

\section{METHODS}

Bacterial strains and culture conditions. $P$. gingivalis W83 and its derivatives were grown anaerobically at $37^{\circ} \mathrm{C}$ in enriched $\mathrm{BHI}$ broth,

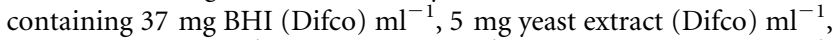
$1 \mathrm{mg} \mathrm{L}$-cysteine $\mathrm{ml}^{-1}, 5 \mu \mathrm{g}$ haemin $\mathrm{ml}^{-1}$ and $1 \mu \mathrm{g}$ menadione $\mathrm{ml}^{-1}$. When necessary, $20 \mu \mathrm{g}$ chloramphenicol $\mathrm{ml}^{-1}$ or $10 \mu \mathrm{g}$ erythromycin $\mathrm{ml}^{-1}$ was added to the medium. E. coli BL21 (Promega), used for protein purification, was grown aerobically in $2 \times$ TY broth (Difco) at $37^{\circ} \mathrm{C}$ with $100 \mu \mathrm{g}$ ampicillin $\mathrm{ml}^{-1}$.

Construction of mutant strains of $\boldsymbol{P}$. gingivalis. A thaA-deficient mutant strain designated KO100 was constructed by transformation of $P$. gingivalis W83 with a DNA construct containing the chloramphenicol-resistance gene (cat) flanked by targeting sequences for pg1401. The upstream targeting sequence, the cat gene and the downstream targeting sequence were individually amplified from pCM18 (Hansen et al., 2001) or genomic DNA prepared using a Wizard Genomic DNA purification kit (Promega). The cat gene was amplified with the primers $090507-\mathrm{cm}-\mathrm{F} 7$ and $090507-\mathrm{cm}-\mathrm{R} 8$ (Table 1). The flanking sequence upstream of tnaA was amplified using the primers 090507-tn-F1 and 090507-tn-R3, which are homologous to the $5^{\prime}$ end of the cat fragment. Amplification of the flanking sequence downstream of tnaA was carried out with the primers 090507-tn-F4 and 090507-tn-R6, which have homology with the $3^{\prime}$ end of the cat fragment. Finally, the amplicons were linked using the PCR-based overlap extension method (Horton et al., 1989).

Likewise, restoration of tnaA in the deficient mutant strain KO100 was performed by replacement of cat with tnaA from strain W83 linked to a cassette of the erythromycin-resistance genes ermFermAM. The DNA fragment used for transformation was prepared using the PCR-based overlap extension method as described above. The ermF-ermAM cassette was amplified from pVA2198 with the primers 021208-ermAF-f9 and 021208-ermAF-r10. The plasmid was provided by Drs Hasegawa and Yoshimura of Aichi-Gakuin University (Nagoya, Japan). The flanking sequence upstream of tnaA was amplified using the primers 021208 -tn-f3 and 021208-tn-r4, which are homologous to the $5^{\prime}$ end of the ermF-ermAM cassette. The DNA fragment containing tnaA and the flanking sequence downstream of tnaA were amplified with the primers 021208-tn-f6 and 090507-tn-R5, which are homologous to the $3^{\prime}$ end of the ermF-
ermAM cassette. The three amplified DNA fragments were then linked using overlap extension PCR.

Electroporation of $P$. gingivalis cells was performed using the method of Nakayama et al. (1995) with minor modifications. Briefly, an overnight enriched BHI culture was diluted $1: 5$ in $5 \mathrm{ml}$ fresh enriched BHI and incubated for $8 \mathrm{~h}$ at $37{ }^{\circ} \mathrm{C}$ to obtain competent cells in the exponential phase. The cells were collected and washed five times with electroporation solution $(0.3 \mathrm{M}$ sucrose), and then resuspended in $100 \mu \mathrm{l}$ of the solution. The PCR constructs for transformation (approx. $5 \mu \mathrm{g}$ ) were added to $80 \mu \mathrm{l}$ of the cell suspension. The mixtures were pulsed with a Gene Pulser apparatus (Bio-Rad) at $2.0 \mathrm{kV}$ with a time constant of $5 \mathrm{~ms}$. The cell suspensions were then diluted with $10 \mathrm{ml}$ prewarmed enriched $\mathrm{BHI}$ broth and incubated anaerobically at $37^{\circ} \mathrm{C}$ for $24 \mathrm{~h}$. Aliquots of the cell suspension were plated on enriched tryptic soy agar (containing, per litre, $40 \mathrm{~g}$ tryptic soy broth, $5 \mathrm{~g}$ BHI, $1 \mathrm{~g}$ L-cysteine, $5 \mathrm{mg}$ haemin, $1 \mathrm{mg}$ menadione and $20 \mathrm{~g}$ agar) plus $20 \mu \mathrm{g}$ chloramphenicol ml${ }^{-1}$ or $10 \mu \mathrm{g}$ erythromycin $\mathrm{ml}^{-1}$ and incubated anaerobically for 5 days at $37^{\circ} \mathrm{C}$.

Southern hybridization experiments. Southern hybridization analysis was performed using non-radioactive DIG-labelled PCR probes that were PCR amplified with a DIG DNA labelling kit (Roche Diagnostics). Genomic DNA digested with SmaI was separated on a $0.8 \%$ agarose gel by electrophoresis and transferred to a nylon membrane. The probes for tnaA, cat and ermF were made by PCR amplification with PCR DIG Labelling Mix (Roche Diagnostics). The PCR products were purified using a Wizard SV Gel and PCR CleanUp System (Promega). The membranes were hybridized for $6 \mathrm{~h}$ under high-stringency conditions with one of the probes, as previously described (Church \& Gilbert, 1984).

RT-PCR and RNA ligase-mediated rapid amplification of CDNA ends (RLM-RACE). Total RNA was extracted from a $P$. gingivalis W83 culture brought to exponential growth using FastPrep Blue tubes (Bio 101) as previously described (Yoshida et al., 2003a). Contaminating DNA in the samples was eliminated by digestion with RNase-free DNase (Takara Bio). The total RNA obtained was used for the following two analyses.

RT-PCR was performed as described by Yoshida et al. (2003a). Briefly, RNA was reverse-transcribed into single-stranded cDNA using PrimeScript Reverse Transcriptase (Takara Bio) according to the manufacturer's instructions. The gene-specific primers used in RT-PCR are listed in Table 1. Each reverse primer for RT-PCR analysis was also used to synthesize a cDNA from a specific mRNA in the total RNA. The reaction mixtures used as negative controls contained no reverse transcriptase, so that the existence of contaminating genomic DNA in the samples could be evaluated.

RLM-RACE was used to determine the transcription start site of tnaA with total RNA. Rapid amplification of $5^{\prime}$ cDNA ends was carried out using a FirstChoice RLM-RACE kit (Ambion) according to the manufacturer's instructions. In brief, a 45 base RNA adaptor was ligated to the RNA population using T4 RNA ligase. This RNA population was then used as a template for a random-primed reverse transcription reaction. The cDNA product of this reaction was used as a template for PCR using a tnaA-specific outer primer (RACE outer tnaA primer) and a reverse primer to the adaptor (RACE outer adaptor primer). The PCR conditions were as follows: $94{ }^{\circ} \mathrm{C}$ for $2 \mathrm{~min} ; 35$ cycles of $94{ }^{\circ} \mathrm{C}$ for $15 \mathrm{~s}, 60^{\circ} \mathrm{C}$ for $20 \mathrm{~s}$ and $72{ }^{\circ} \mathrm{C}$ for $30 \mathrm{~s}$; and $72{ }^{\circ} \mathrm{C}$ for $5 \mathrm{~min}$. The identity of the product was confirmed using inner gene-specific primers (RACE inner tnaA primer and RACE inner adaptor primer). After the amplicon was purified and then ligated into pMCL210 (Nakano et al., 1995), E. coli was transformed with the ligated mixture. The plasmids isolated from ten different colonies were sequenced with an ABI 3730 Genetic Analyzer (Applied 
Table 1. Oligonucleotide primers used in this study

\begin{tabular}{|c|c|}
\hline Designation & Sequence $\left(5^{\prime}-3^{\prime}\right)^{*}$ \\
\hline \multicolumn{2}{|l|}{ Construction of mutants } \\
\hline $090507 \mathrm{~cm}-\mathrm{F} 7$ & ATGGAGAAAAAAATCACTGGA \\
\hline $090507 \mathrm{~cm}-\mathrm{R} 8$ & TTACGCCCCGCCCTGCCACTC \\
\hline 090507-tn-F1 & CGAAAAGTCCTTGTCGTGA \\
\hline 090507-tn-R3 & CCAGTGATTTTTTTCTCCATCATTTTAATGCGGTAGGATTC \\
\hline 090507-tn-F4 & GCAGGGCGGGGCGTAATCACTTCACTGTTGAGCTGG \\
\hline 090507-tn-R6 & ATCGGTATTCTTGGATTGGTA \\
\hline 021208-ermAF-f9 & TTTATTGCTTATTATCCGCACCCAAA \\
\hline 021208-ermAF-r10 & CGACTCATAGAATTATTTCCTCCCGTT \\
\hline 021208-tn-f3 & GGCAGATGGGACGGAATATCT \\
\hline 021208-tn-r4 & TTTGGGTGCGGATAATAAGCAATAAATTTACCGGAGGAGGTTCCTTT \\
\hline 021208-tn-f6 & AACGGGAGGAAATAATTCTATGAGTCGACTAACTTGCCGCCCAATTAAA \\
\hline 090507-tn-R5 & GAATTAACAAACAAAATATACGCC \\
\hline \multicolumn{2}{|l|}{ RT-PCR } \\
\hline 032508-pg03-f1 & GGTGGTATGATAGGAGGTATTA \\
\hline 040308-pg03-r1 & CCACTCCGAAGACAATG \\
\hline 032508-pg03-f2 & GGATTGGTCGTTCTTCTTA \\
\hline 033108-pg02-r2 & TGAGAATAGGATTGGGATTC \\
\hline 032508-pg02-f3 & AATCAGGGAGCTTTCAAG \\
\hline 032508-pg01-r3 & TGGCATTCTTCATATTATAGTATG \\
\hline 032508-pg01-f4 & ACTTCACTGTTGAGCTGGA \\
\hline 033108-pg01-r4 & ACTCTGTCAGTGCCGAAC \\
\hline 032598 pg-f5 & AAACAGGTTGTCCGTCAG \\
\hline 032598 pg-r5 & TCCTGTATAAATTAAAGGCGA \\
\hline 060908-Pgtn-f6 & AGAATATACGTGAAGTGAGCG \\
\hline 060908-Pgtn-r6 & AAAGTCTGAGCGATGAACTC \\
\hline \multicolumn{2}{|l|}{ RLM-RACE } \\
\hline RACE outer adaptor primer & GCGAGCACAGAATTAATACGACT \\
\hline RACE inner adaptor primer & CGCGGATCCGAACACTGCGTTTGCTGGCTTTGATG \\
\hline RACE outer tnaA primer & CCGGAATCAGTGAGCAA \\
\hline RACE inner tnaA primer & ATACATAGTCGCTCTTGAGG \\
\hline \multicolumn{2}{|l|}{ Purification of TnaA } \\
\hline 090407-F1 & AAGGATCCGAATTACCTTTTTCAGAATCCTACC \\
\hline 090407-R1 & AAGTCGACTTACTTGGCTTTTTCCAGC \\
\hline
\end{tabular}

${ }^{\star}$ The nucleotides underlined in each primer sequence are the positions of restriction endonuclease sites incorporated to facilitate cloning. Bold letters show overlapping regions of the $5^{\prime}$ or $3^{\prime}$ ends of the cat gene or the ermF-ermAM cassette.

Biosystems). The sequences were analysed using Vector NTI software (Invitrogen).

Preparation of crude enzyme extracts. Crude enzyme extracts of $P$. gingivalis were prepared as described by Yoshida et al. (2002). Briefly, cells grown to an $\mathrm{OD}_{600}$ of about 0.8 were harvested from $50 \mathrm{ml}$ of culture and then washed with PBS. The cells were sonicated five times for $30 \mathrm{~s}$ at $1 \mathrm{~min}$ intervals. The supernatant was collected after centrifugation at $15000 \mathrm{~g}$ for $30 \mathrm{~min}$ at $4{ }^{\circ} \mathrm{C}$. The concentration of proteins in the crude enzyme extract was determined using a protein assay reagent (Bio-Rad) with BSA as a standard. The samples were stored at $-20{ }^{\circ} \mathrm{C}$ after adding the same volume of $80 \%(\mathrm{v} / \mathrm{v})$ glycerol.

Purification of recombinant TnaA. Recombinant TnaA protein of P. gingivalis was purified using the expression vector pGEX-6P-1 (GE Healthcare) as described by Yoshida et al. (2002). The coding sequence of tnaA was amplified by PCR with KOD DNA polymerase (Toyobo) from genomic DNA of $P$. gingivalis W83 using the primers 090407-F1 and 090407-R1 and ligated into the pGEX-6P-1 vector via the BamHI and XhoI restriction sites, juxtaposing the tnaA gene downstream of the coding sequence for glutathionine $S$-transferase (GST) and a PreScission protease cleavage site. The resulting plasmid pGEW101-1 was sequenced to verify the correctness of the PCR amplification of the 1523 bp insert and transformed into E. coli BL21 cells. Production cultures of $500 \mathrm{ml}$ were inoculated $1: 1000$ with an overnight culture and grown to an $\mathrm{OD}_{600}$ of 0.7 at $37^{\circ} \mathrm{C}$. After induction of protein expression with $0.5 \mathrm{mM}$ IPTG, the cells were incubated at $37{ }^{\circ} \mathrm{C}$ for another $2 \mathrm{~h}$. The cells were then harvested by centrifugation at $4{ }^{\circ} \mathrm{C}$, resuspended in $12 \mathrm{ml} \mathrm{PBS}$, and lysed by ultrasonication. Cell debris was sedimented by centrifugation, and the portion of GST fusion protein that remained in the supernatant was adsorbed onto affinity matrix glutathione-Sepharose 4B and cleaved with PreScission protease according to the manufacturer's protocol (GE Healthcare). The concentration of proteins was determined as described by Pace et al. (1995). The purity of the samples was analysed by SDS-PAGE.

$\mathrm{N}$-terminal amino acid sequence determination was carried out to confirm the homogeneity of the recombinant protein. Briefly, the 
protein separated by SDS-PAGE was transferred electrophoretically to a PVDF membrane. The band visualized by Coomassie brilliant blue was excised and analysed with a Procise 49X cLC protein sequencer (Applied Biosystems).

TnaA apoenzyme was prepared by dialysing against $20 \mathrm{mM}$ potassium phosphate or sodium phosphate buffer ( $\mathrm{pH} 7.5)$ for $24 \mathrm{~h}$. Reconstitution of the holoenzyme was achieved by incubation of the apoenzyme with $0.1 \mathrm{mM}$ PLP at $37{ }^{\circ} \mathrm{C}$ for $30 \mathrm{~min}$ in darkness as described by Raibaud \& Goldberg (1976).

Gel-filtration chromatography. A prepacked gel-filtration column (Hiroad 16/60 Superdex; GE Healthcare) was used. The mobile phase used for apoenzyme analysis was identical to that used for dialysis to prepare each apoenzyme $(20 \mathrm{mM}$ potassium phosphate or sodium phosphate buffer, $\mathrm{pH}$ 7.5) to remove the effect of the other cation. For holoenzyme analysis, each phosphate buffer containing $0.1 \mathrm{mM}$ PLP was used to avoid the release of PLP from the holoenzyme. The column was run at $0.5 \mathrm{ml} \mathrm{min}{ }^{-1}$ at $4{ }^{\circ} \mathrm{C}$. The enzyme elution was monitored at $280 \mathrm{~nm}$. The size of each protein was estimated using a standard curve made with five commercially available proteins (Gel Filtration Calibration kit HMW, GE Healthcare).

HPLC analysis. The indole production in an enzymic reaction was evaluated using reversed-phase HPLC as described by Krstulovic \& Matzura (1979). The reaction mixture contained the following reagents in a final volume of $100 \mu \mathrm{l}: 167 \mathrm{mM}$ potassium phosphate buffer ( $\mathrm{pH} 7.5$ ), $0.165 \mathrm{mM}$ PLP, $0.2 \mathrm{mM}$ reduced glutathione, $0.25 \mathrm{mg}$ BSA ml${ }^{-1}, 2 \mathrm{mM}$ L-tryptophan and $50 \mu \mathrm{g} \mathrm{ml} \mathrm{m}^{-1}$ crude extract of $P$. gingivalis strain W83, KO100 or RS101. After layering with $100 \mu \mathrm{l}$ toluene, the mixture was incubated for $2 \mathrm{~h}$ at $37^{\circ} \mathrm{C}$. An aliquot $(20 \mu \mathrm{l})$ of toluene from the sample tube was injected onto a Capcell Pak C18 UG120 column $(4.6 \mathrm{~mm} \times 150 \mathrm{~mm}$; Shiseido $)$ with $50 \%(\mathrm{v} / \mathrm{v})$ methanol/water as the mobile phase at a flow rate of $0.5 \mathrm{ml}$ $\min ^{-1}$ at $40{ }^{\circ} \mathrm{C}$. Excitation and emission wavelengths of 285 and $320 \mathrm{~nm}$, respectively, were used.

Enzyme assay. The degradation of L-tryptophan by purified tryptophanase was examined by measuring the formation of indole as described by Morino \& Snell (1970) with minor modifications. Briefly, the reaction mixture contained $200 \mathrm{mM}$ potassium or sodium phosphate buffer ( $\mathrm{pH} 7.5$ ), $0.165 \mathrm{mM}$ PLP, $0.2 \mathrm{mM}$ reduced glutathione, $0.25 \mathrm{mg} \mathrm{BSA} \mathrm{ml}^{-1}, 10 \mu \mathrm{g}$ purified tryptophanase $\mathrm{ml}^{-1}$, and varying concentrations of L-tryptophan. After being layered with $100 \mu$ toluene, the reaction mixture was prewarmed for $5 \mathrm{~min}$ at $37{ }^{\circ} \mathrm{C}$. The reaction was initiated by the addition of substrate solution. After $10 \mathrm{~min}$ incubation, the reaction was terminated by the addition of $1 \mathrm{ml}$ Ehrlich's reagent, which was prepared daily by mixing 5 vols $5 \%(\mathrm{w} / \mathrm{v})$-dimethylaminobenzaldehyde in $95 \%(\mathrm{v} / \mathrm{v})$ ethanol with 12 vols $5 \%(\mathrm{v} / \mathrm{v}) \mathrm{H}_{2} \mathrm{SO}_{4}$ in 1-butanol. After $20 \mathrm{~min}$ at room temperature, the mixture was centrifuged at $15000 \mathrm{~g}$ for $2 \mathrm{~min}$ to remove insoluble material. The supernatant was examined spectrophotometrically at $568 \mathrm{~nm}$. The amount of indole was calculated from a standard curve. The kinetic parameters were computed from a Lineweaver-Burk transformation $\left(v^{-1}\right.$ versus $\left.S^{-1}\right)$ of the Michaelis-Menten equation, where $v\left(\mathrm{mmol} \min ^{-1} \mathrm{~g}^{-1}\right)$ represented the formation of indole and $S(\mathrm{mM})$ was the concentration of L-tryptophan. The $k_{\text {cat }}$ value was calculated from the $V_{\max }$ value and the molecular mass of $P$. gingivalis tryptophanase. Data were obtained from three independent experiments.

The degradation of S-ethyl-L-cysteine, S-methyl-L-cysteine, L-cysteine, $\mathrm{L}$-alanine and $\mathrm{L}$-serine was measured by assaying pyruvate formation, as previously described (Yoshida et al., 2002). The assays were carried out in $100 \mu \mathrm{l}$ reaction mixtures containing $200 \mathrm{mM}$ potassium phosphate buffer ( $\mathrm{pH} 7.6$ ), $0.165 \mathrm{mM}$ PLP, $1 \mu \mathrm{g}$ purified enzyme, and varying concentrations of each substrate. After $5 \mathrm{~min}$ incubation at $37^{\circ} \mathrm{C}$, the reactions were terminated by the addition of $50 \mu \mathrm{l}$ of
$4.5 \%(\mathrm{v} / \mathrm{v})$ trichloroacetic acid. The reaction mixtures were then centrifuged, and $100 \mu \mathrm{l}$ aliquots of the supernatants were added to $300 \mu \mathrm{l} 0.67 \mathrm{M}$ sodium acetate ( $\mathrm{pH} 5.2$ ) containing $0.017 \%(\mathrm{w} / \mathrm{v}) 3-$ methyl-2-benzothiazolinone hydrazone. After incubation at $50{ }^{\circ} \mathrm{C}$ for $30 \mathrm{~min}$, the absorbance at $335 \mathrm{~nm}$ was determined. The amounts of pyruvate were calculated from a standard curve prepared using crystalline sodium pyruvate. Data were obtained from three independent experiments.

\section{RESULTS}

\section{Organization of the tnaA homologue in P. gingivalis W83}

The tnaA genes that encode tryptophanase in Pr. vulgaris (Kamath \& Yanofsky, 1992), Enterobacter aerogenes (Kawasaki et al., 1993), H. influenzae (Martin et al., 1998) and E. coli (Deeley \& Yanofsky, 1981; Rezwan et al., 2004) have been sequenced. A database search identified the ORF pg1401, which was assigned by the J. Craig Venter Institute (http://www.jcvi.org/), as a homologue of the tnaA gene in the genome of $P$. gingivalis W83 (Nelson et al., 2003). The ORF (1380 bp) is slightly shorter than those of the tnaA genes from the bacteria described above (1389$1416 \mathrm{bp}$ ). In those organisms, tnaA is located between tnaC, which encodes a leader peptide, and tnaB, which encodes tryptophan permease; the latter consists of an operon with tnaA (Deeley \& Yanofsky, 1981) (Fig. 1a). By contrast, the gene upstream of pg1401 in P. gingivalis, pg1402, encodes a putative endonuclease/exonuclease/ phosphatase-family protein. The amino acid sequence encoded by the gene downstream of pg1401 contains an inosine monophosphate cyclohydrolase domain that is involved in purine biosynthesis. We have designated this gene orf $X$, since the ORF was not identified in the database. Unexpectedly, no genes homologous to tna $B$ or tna $C$ were identified either in the pg1401 region or in the wholegenome sequence of $P$. gingivalis W83, showing that the gene organization of this region in $P$. gingivalis is different from that in other bacteria. However, the amino acid sequence deduced from pg1401 shows $48.1 \%, 50.9 \%$, $42.0 \%$ and $44.9 \%$ identity with the deduced sequences from Pr. vulgaris, Ent. aerogenes SM-18, H. influenzae Eagan, and E. coli K-12, respectively.

\section{Transcription of the tnaA region in $P$. gingivalis W83}

RT-PCR was used to characterize the transcripts of the pg1401 region in $P$. gingivalis W83. The locations of the primer pairs used to detect intragenic and intergenic regions are shown in Fig. 1(a). RT-PCR amplification generated products of the expected size from an oligonucleotide pair complementary to pg1404/pg1403 (Fig. 1b). In contrast, no PCR products corresponding to the regions spanning the borders of pg1403/pg1402, pg1402/pg1401 or pg1401/orfX were amplified, indicating that pg1401 was transcribed alone. No PCR products were observed from 
(a)

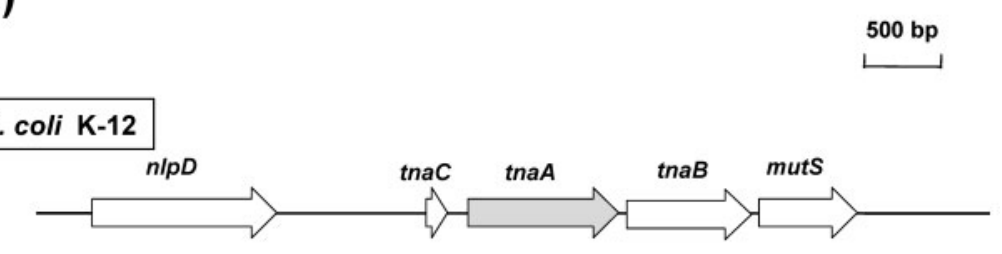

P. gingivalis W83

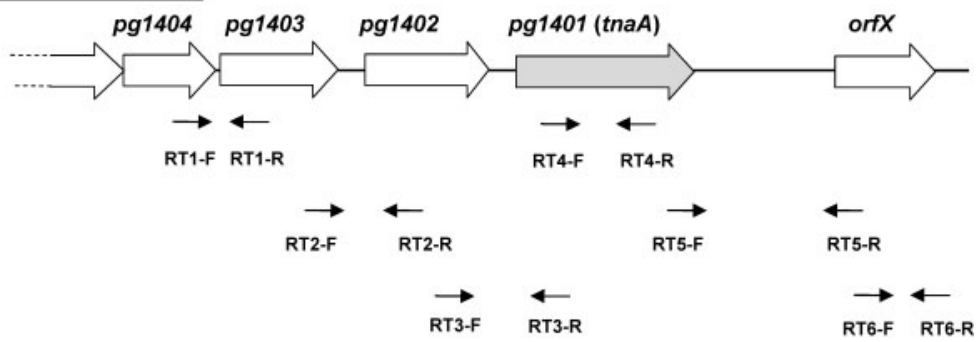

(b)

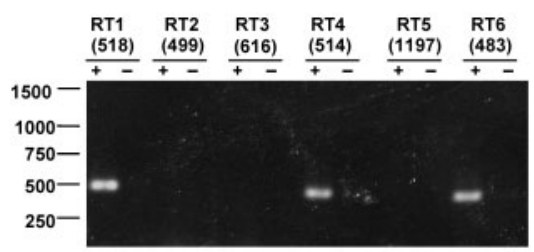

Fig. 1. Genetic organization and transcriptional analysis of the tnaA region of $P$. gingivalis W83. (a) Gene arrangements of the tha $A$ region in $E$. coli $\mathrm{K}-12$ and $P$. gingivalis W83. The DNA sequence of each region was obtained from the database. Large and small arrows indicate the positions of the ORF and the primers used for RT-PCR, respectively. (b) RT-PCR analysis of tnaA gene expression. Total RNA was prepared from a culture in the exponential growth phase. The expected size (bp) of each PCR amplicon is shown in parentheses. Lanes marked $(+)$ are standard RT-PCR amplifications. Lanes marked (-) are negative controls containing no cDNA. The positions of DNA size standards (in $\mathrm{bp}$ ) are indicated on the left. (c) Determination of the transcription start site by RLM-RACE. The coding region starting with ATG (bold and underlined) is shown with the upstream promoter region in italics. The identified transcriptional start site is shaded and boxed. The positions of the tnaA-specific outer and inner primers used for RLM-RACE are indicated by arrows.

total RNA preparations that had not been first reverse transcribed, demonstrating that the RT-PCR products were not derived from contaminated chromosomal DNA. The data also showed expression of $\operatorname{orf} X$, which has not been recognized as an ORF in the database (Fig. 1b).

The transcription start site of pg1401 was determined by RLM-RACE using total RNA extracted from $P$. gingivalis W83 grown to the early exponential phase. PCR fragments amplified with inner primers were subjected to DNA sequencing of the upstream region up to the transcription start site of $p g 1401$. The junction of the adaptor with $P$. gingivalis DNA is the $5^{\prime}$ end of the transcript. As shown in Fig. 1(c), one clear ending sequence corresponding to a position $52 \mathrm{bp}$ upstream of the first nucleotide of the translation initiation codon was obtained by sequencing of the 5' RLM-RACE PCR product in all ten plasmids analysed.

\section{The tryptophanase of $P$. gingivalis W83 is encoded by pg1401}

To determine whether the product of the pg1401 gene functions as a tryptophanase, a mutant $P$. gingivalis W83 strain, in which the $1.4 \mathrm{~kb}$ gene was replaced by the $0.7 \mathrm{~kb}$ cat gene, was constructed (Fig. 2a). The DNA fragment for transformation was prepared using overlap extension PCR. Integration of the PCR products at the expected location in the chromosome of the resulting mutant strain, designated KO100, was confirmed by Southern blot analysis (Fig. 2b). HPLC analysis demonstrated that incubation of crude extract from KO100 with L-tryptophan showed no indole production (Fig. 3). Similarly, a pg1401-restored strain, designated RS101, was constructed from strain KO100, in which the cat gene was replaced by $p g 1401$ linked to the ermF-ermAM cassette (Fig. 2a). As expected, the ability of 
(a)

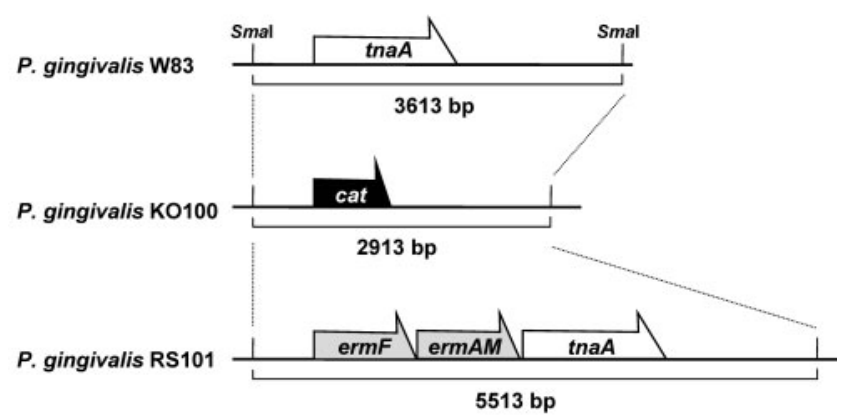

(b)

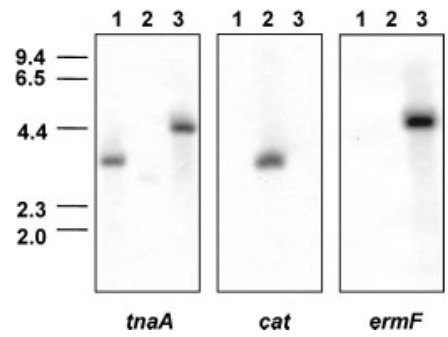

Fig. 2. Construction of derivatives of $P$. gingivalis W83. (a) Chromosomal gene arrangement of the tna $A$ region in the parental and mutant strains. The size of each fragment in bp is shown. (b) Verification of the derivatives by Southern blot hybridization. Each chromosomal DNA was digested with Smal. Hybridizations with the tna $A$ gene probe (left panel), the cat gene probe (centre panel) and the ermF probe (right panel) were carried out at $60{ }^{\circ} \mathrm{C}$ for $6 \mathrm{~h}$. Lanes: 1, P. gingivalis W83; 2, P. gingivalis KO100; $3, P$. gingivalis RS101. The positions of DNA size standards (in kbp) are shown.

crude extracts to produce indole from L-tryptophan was restored by replacement of the cat gene with $p g 1401$. These results confirm that the pg1401 gene encodes tryptophanase, the only enzyme associated with indole production in $P$. gingivalis. Based on these results, the pg1401 gene of $P$. gingivalis W83 was redesignated tnaA.

\section{Enzymic properties of recombinant TnaA from P. gingivalis W83}

To characterize the enzymic properties of tryptophanase from $P$. gingivalis W83, recombinant TnaA was purified using the pGEX-6P-1 vector system. All purification steps were monitored by SDS-PAGE analysis, as shown in Fig. 4 . The protein obtained was judged to be homogeneous in an SDS-PAGE gel stained with Coomassie brilliant blue. The molecular mass of the denatured polypeptide agreed well with the predicted molecular mass $(52.5 \mathrm{kDa})$. The quaternary structure of the recombinant protein might be a heterooligomer consisting of subunits derived from both $P$. gingivalis and E. coli tryptophanase, since the host E. coli BL21 produces its own tryptophanase. However, this possibility was excluded by protein sequence analysis, (a)

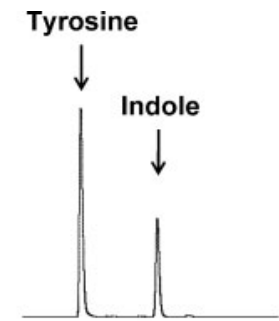

(b)

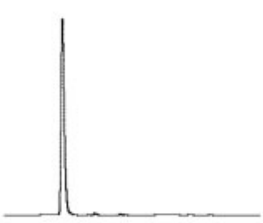

(c)

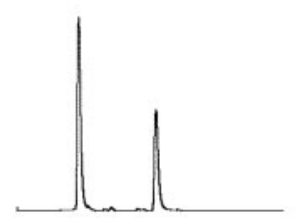

(d)

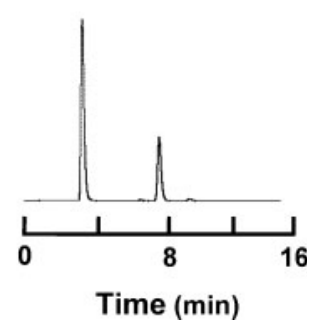

Fig. 3. Reversed-phase HPLC profiles of indole production from L-tryptophan. An aliquot $(20 \mu \mathrm{l})$ of toluene that had been layered on the reaction mixture was injected onto a column with L-tyrosine as an internal standard. The reaction mixtures contained (a) crude extract of $P$. gingivalis W83, (b) crude extract of $P$. gingivalis KO100, (c) crude extract of $P$. gingivalis RS101 or (d) purified recombinant TnaA of $P$. gingivalis W83. Arrows indicate the elution positions of indole and tyrosine.

which showed that the N-terminal amino acid sequence of the protein obtained was GPLGSEL. The first five amino acids (i.e. GPLGS) are derived from the cloning site of pGEX-6P-1, whereas the remaining two correspond to the second and third amino acids of $P$. gingivalis tryptophanase. The forward primer used for amplification of $P$. gingivalis tnaA (Table 1) did not contain the start codon so that the GST-TnaA fusion protein was produced. In contrast, no findings suggesting that the protein contained subunits from E. coli tryptophanase were obtained, indicating that the recombinant tryptophanase of $P$. gingivalis W83 formed a homooligomer. Indole production by the recombinant enzyme was confirmed by HPLC (Fig. 3d).

The kinetic activity of the recombinant TnaA protein was spectrophotometrically evaluated by determination of its production of indole from L-tryptophan. When potassium 


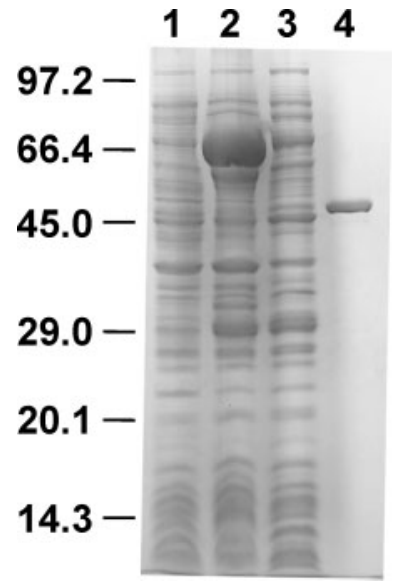

Fig. 4. SDS-PAGE analysis of GST-TnaA protein expression and purification. Recombinant protein was purified by affinity chromatography on glutathione-Sepharose 4B resin and digested with PreScission protease. Lane 1, total proteins from sonicated $E$. coli BL21 cells harbouring pGEW101-1 (no induction). Lane 2, total proteins from sonicated BL21 cells harbouring pGEW101-1 (induction by IPTG). Lane 3, total proteins from sonicated BL21 cells, after loading on affinity resin. Lane 4, flowthrough following PreScission protease digestion of GST-TnaA fusion protein bound to glutathione-Sepharose 4B. Each protein sample (approx. $5 \mu \mathrm{g}$ ) was subjected to SDS-PAGE and stained with Coomassie brilliant blue. Positions of molecular mass markers (in $k D a$ ) are shown.

phosphate buffer was used in the enzymic reaction, the $K_{\mathrm{m}}$ and $k_{\text {cat }}$ values of the protein were $0.20 \pm 0.01 \mathrm{mM}$ and $1.37 \pm 0.06 \mathrm{~s}^{-1}$, respectively. When the reaction was performed in sodium phosphate buffer, the values were $0.09 \pm 0.01 \mathrm{mM}$ and $0.24 \pm 0.01 \mathrm{~s}^{-1}$, respectively. Thus, the enzymic activity of TnaA from $P$. gingivalis W83 is much higher in the presence of $\mathrm{K}^{+}$than $\mathrm{Na}^{+}$. On the basis of these results, the following enzymic characterization experiments were performed using potassium phosphate buffer with the active holoform of TnaA.

The effects of $\mathrm{pH}$ and temperature on the enzymic activity of TnaA were determined by using L-tryptophan as a substrate (Fig. 5). The activity of the purified enzyme was highest at $\mathrm{pH}$ 7.5. The enzyme was stable up to $40{ }^{\circ} \mathrm{C}$, but only $40 \%$ of the activity remained at $60{ }^{\circ} \mathrm{C}$. The enzyme was completely inactivated at temperatures above $70{ }^{\circ} \mathrm{C}$.

To identify substrates other than L-tryptophan for the recombinant TnaA of $P$. gingivalis, several other compounds were assayed. The specificity of the purified enzyme to various substrates is shown in Table 2. In the reactions, enzymic degradation of the substrates invariably resulted in the formation of pyruvate. Thus, the breakdown of substrates other than L-tryptophan was determined by assaying the production of pyruvate. Degradation of Ltryptophan was measured as described above, because indole inhibits the assay using 3-methyl-2-benzothiazoli- (a)

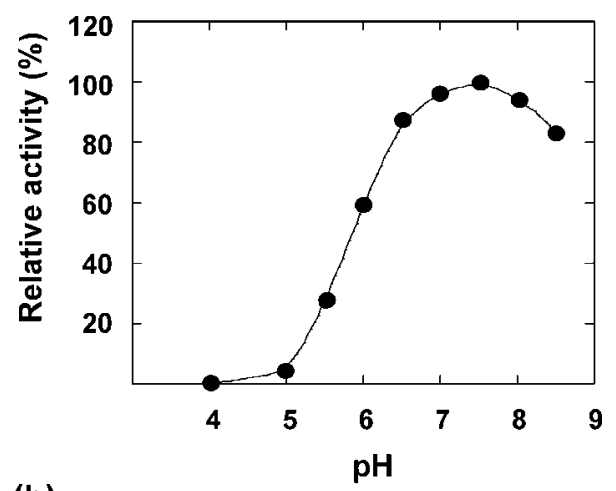

(b)

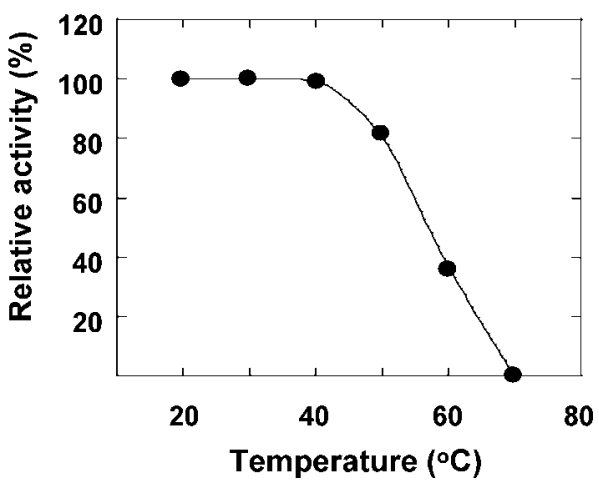

Fig. 5. Effect of $\mathrm{pH}(\mathrm{a})$ and temperature (b) on indole formation from L-tryptophan by the recombinant TnaA of $P$. gingivalis W83. To examine the effect of $\mathrm{pH}$ the enzyme was incubated with $2 \mathrm{mM}$ L-tryptophan at $37{ }^{\circ} \mathrm{C}$ for $10 \mathrm{~min}$ in $167 \mathrm{mM}$ potassium phosphate. To examine the effect of temperature the same concentration of the enzyme was incubated with $2 \mathrm{mM}$ L-tryptophan for $10 \mathrm{~min}$ in $167 \mathrm{mM}$ potassium phosphate $(\mathrm{pH}$ 7.5). The results shown were obtained from two independent experiments.

none hydrazone to detect pyruvate formation. The kinetic parameters of $P$. gingivalis TnaA for $S$-ethyl-L-cysteine were comparable with those for L-tryptophan. In contrast, the $k_{\text {cat }}$ and $k_{\text {cat }} / K_{\mathrm{m}}$ values of the enzyme for $S$-methyl-Lcysteine were much lower than those for L-tryptophan. The enzyme had no detectable elimination activity with Lalanine, L-serine or L-cysteine as substrate.

\section{Quaternary structure of recombinant TnaA from P. gingivalis W83}

We hypothesized that the difference in enzymic activity of $P$. gingivalis TnaA in the presence of different monovalent cations $\left(\mathrm{K}^{+}\right.$and $\mathrm{Na}^{+}$) (Table 2) could be due to a structural change in the enzyme. To evaluate this hypothesis, the quaternary structures of the apo- and holoform of $P$. gingivalis TnaA in the presence of each cation were examined by gel-filtration chromatography (Fig. 6a). In contrast to the results predicted by the hypothesis, no matter which buffer (potassium or sodium 


\section{Table 2. Steady-state kinetic parameters for TnaA from $P$. gingivalis W83}

The reaction was performed in the presence of $200 \mathrm{mM}$ potassium phosphate buffer ( $\mathrm{pH}$ 7.5). The values calculated from the reaction mixtures containing $200 \mathrm{mM}$ sodium phosphate buffer ( $\mathrm{pH} 7.5$ ) instead of potassium phosphate buffer are shown in parentheses. Values are given as the means \pm SD of three independent experiments. No detectable elimination activity with L-alanine, L-serine or L-cysteine as substrate was observed.

\begin{tabular}{|lccc|}
\hline Substrate & $\boldsymbol{K}_{\mathbf{m}}(\mathbf{m M})$ & $\boldsymbol{k}_{\text {cat }}\left(\mathbf{s}^{-\mathbf{1}}\right)$ & $\boldsymbol{k}_{\text {cat }} / \boldsymbol{K}_{\mathbf{m}}\left(\mathbf{m M}^{-\mathbf{1}} \mathbf{s}^{-\mathbf{1}}\right)$ \\
\hline L-Tryptophan & $0.20 \pm 0.01(0.09 \pm 0.01)$ & $1.37 \pm 0.06(0.24 \pm 0.01)$ & $6.87 \pm 0.1(2.53 \pm 0.09)$ \\
S-Methyl-L-cysteine & $2.04 \pm 0.18$ & $0.50 \pm 0.05$ & $0.25 \pm 0.004$ \\
S-Ethyl-L-cysteine & $0.26 \pm 0.01$ & $1.87 \pm 0.03$ & $7.15 \pm 0.17$ \\
\hline
\end{tabular}

phosphate) was used for dialysis and the mobile phase, both forms of the enzyme eluted at approximately $205.8 \mathrm{kDa}$, as estimated using a standard curve made with commercially available proteins. This size corresponds to the tetramer of $P$. gingivalis TnaA. These results showed that the quaternary structure of $P$. gingivalis TnaA was not affected by $\mathrm{K}^{+}$or $\mathrm{Na}^{+}$.

The protein samples used for gel-filtration chromatography were also scanned by spectrophotometric absorption spectra. The holoenzyme in the potassium phosphate and sodium phosphate buffers displayed a characteristic absorption spectrum common to PLP-dependent enzymes, with band maxima at 337 and $423 \mathrm{~nm}$. These maxima were not observed in the spectra of the apoenzyme. The type of phosphate buffer did not affect the absorption spectra of $P$. gingivalis TnaA, suggesting that the cation $\left(\mathrm{K}^{+}\right.$or $\left.\mathrm{Na}^{+}\right)$ had no significant effect on the binding of PLP. The difference of phosphate buffer did not have marked effects on the spectra of PLP (data not shown).

\section{DISCUSSION}

Tryptophanase degrades tryptophan into pyruvate, ammonia and indole. Of those products, the former two molecules can be used as a carbon or nitrogen source in cells, whereas indole is secreted from the cells. Indole at very high concentrations $(5 \mathrm{mM})$ is toxic to microorganisms, including E. coli, possibly by causing membrane changes that result in the generation of superoxide (Garbe et al., 2000). However, the toxic concentration of indole is approximately 15-fold higher than the physiological concentration observed in stationary-phase supernatants of E. coli. Interestingly, it has been shown that indole has an effect on physiological and pathological functions in bacteria (Anyanful et al., 2005; Hirakawa et al., 2005). Our objective in this study was to determine the molecular basis of indole production in $P$. gingivalis.

The tnaA and tnaB genes constitute the tna operon in $E$. coli (Deeley \& Yanofsky, 1981), Pr. vulgaris (Kamath \& Yanofsky, 1992), Ent. aerogenes (Kawasaki et al., 1993), and $H$. influenzae (Martin et al., 1998). In vitro transcription experiments located the presumptive tna promoter at more than $300 \mathrm{nt}$ from the tnaA initiation codon in E. coli. This promoter requires a cAMP-cAMP receptor protein (CRP) for activity (Deeley \& Yanofsky, 1982). The long transcribed leader region between the promoter and tnaA includes a coding region for a short leader peptide, designated TnaC. This peptide plays an essential role in the full induction of the tna operon, as well as in setting the basal uninduced level of tha expression (Stewart \& Yanofsky, 1986). In contrast, no nucleotide sequences homologous to $t n a B$, tnaC or the CRP-binding region are present around tnaA in $P$. gingivalis. In addition, the gene does not consist of an operon with any genes. These findings suggest that the gene arrangement around tnaA in $P$. gingivalis is unique and that the expression of tnaA is controlled by a mechanism distinct from that in E. coli and other bacteria. The tryptophanase of $E$. coli is overexpressed and becomes one of the most abundant proteins when cells experience alkaline stress (Blankenhorn et al., 1999). The transcriptional data presented here would be helpful for further research along these lines.

When potassium phosphate buffer was used in the reaction mixture, the $K_{\mathrm{m}}$ value $(0.20 \pm 0.01 \mathrm{mM})$ of TnaA from $P$. gingivalis W83 for L-tryptophan was slightly lower than those from the other bacteria, including $E$. coli B (0.32 mM) (Newton et al., 1965; Watanabe \& Snell, 1977) and Bacillus alvei (0.27 mM) (Hoch et al., 1966), indicating that the affinity of $P$. gingivalis tryptophanase to L-tryptophan was comparable with those of $E$. coli and $B$. alvei. Its $k_{\text {cat }}$ and $k_{\text {cat }} / K_{\mathrm{m}}$ values $\left(1.37 \pm 0.06 \mathrm{~s}^{-1}\right.$ and $\left.6.87 \pm 0.1 \mathrm{mM}^{-1} \mathrm{~s}^{-1}\right)$ was also less than those in E. coli (6.8 $\mathrm{s}^{-1}$ and $30 \mathrm{mM}^{-1} \mathrm{~s}^{-1}$ ) (Phillips \& Gollnick, 1989) and Pr. vulgaris $\left(6.3 \mathrm{~s}^{-1}\right.$ and $23 \mathrm{mM}^{-1} \mathrm{~s}^{-1}$ ) (Demidkina et al., 2003). Thus, the enzymic activity of tryptophanase from $P$. gingivalis was lower than that from E. coli and $P r$. vulgaris. This investigation also demonstrated that $P$. gingivalis TnaA still has a weak enzymic activity in the presence of $\mathrm{Na}^{+}$, although $\mathrm{NaCl}$ showed an inhibitory effect on $P$. gingivalis TnaA (data not shown). In contrast, E. coli tryptophanase had almost no enzymic activity in the presence of only $\mathrm{Na}^{+}$(Honda \& Tokushige, 1986). Comparison of the $K_{\mathrm{m}}$ values did not suggest that $\mathrm{Na}^{+}$ lowers the affinity of the substrate to the enzyme. Since the cation in the buffer, $\mathrm{K}^{+}$or $\mathrm{Na}^{+}$, did not appear to affect 
(a)

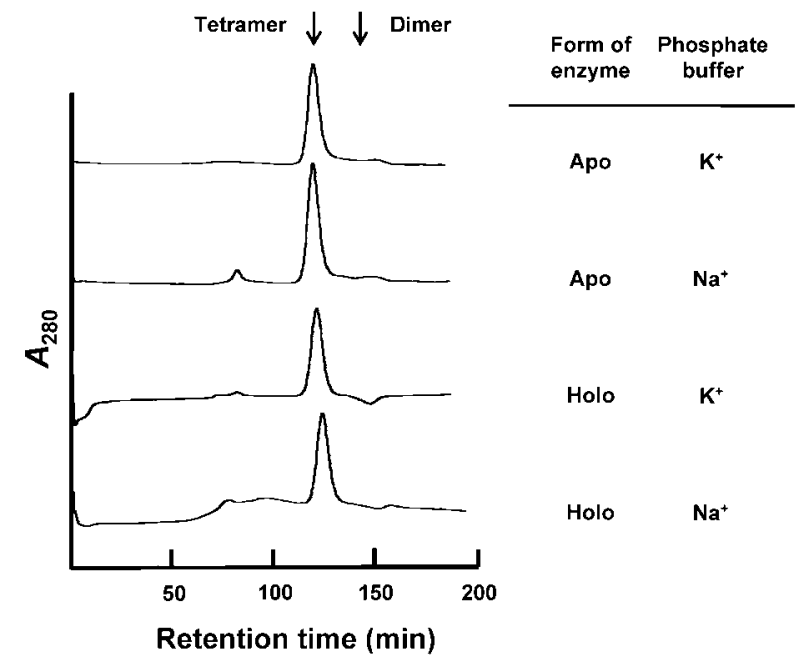

(b)

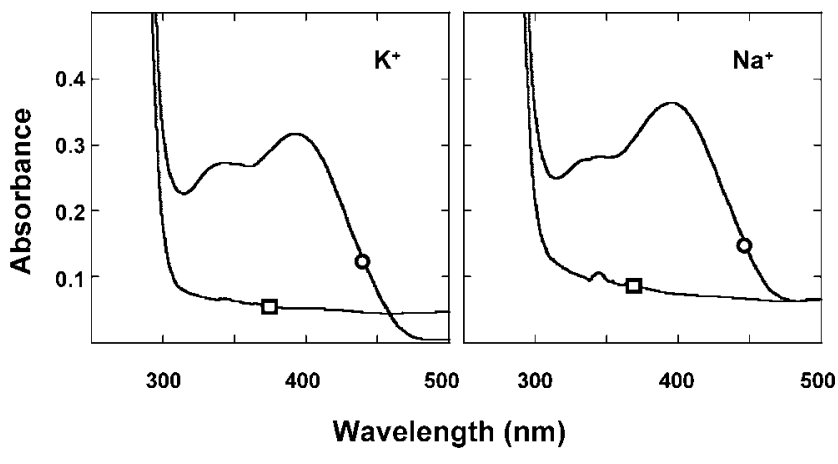

Fig. 6. Effect of $\mathrm{K}^{+}$and $\mathrm{Na}^{+}$on the structure of TnaA from $P$. gingivalis W83. (a) Gel-filtration chromatography. The apoform of $P$. gingivalis TnaA was eluted with potassium or sodium phosphate buffer at $\mathrm{pH} 7.5$, the same buffer as used for dialysis to prepare the apoenzyme. The holoform of $P$. gingivalis TnaA was eluted with potassium or sodium phosphate buffer at $\mathrm{pH} 7.5$ with PLP, the same buffer as used for preparation of the holoenzyme. Arrows indicate the predicted elution positions of the tetramer $(210 \mathrm{kDa})$ and dimer $(105 \mathrm{kDa})$. The flow rate was $0.5 \mathrm{ml} \mathrm{min}{ }^{-1}$. (b) Absorption spectra of recombinant TnaA of $P$. gingivalis W83 $\left(1.5 \mathrm{mg} \mathrm{ml}^{-1}\right.$ ) in $20 \mathrm{mM}$ potassium (left panel) or sodium (right panel) phosphate buffer at pH 7.5. Each protein sample was the same as used for gel-filtration chromatography. $\bigcirc$, Holoenzyme in buffer containing PLP; $\square$, apoenzyme in buffer without PLP.

either the quaternary structure of TnaA from $P$. gingivalis W83 or the binding of PLP to the apoenzyme (Fig. 6), $\mathrm{K}^{+}$ may function as an activator for the catalysing enzyme. Honda \& Tokushige (1986) reported that $\mathrm{NH}_{4}^{+}$is an active cation for E. coli tryptophanase in addition to $\mathrm{K}^{+}$. Morino \& Snell (1967) reported that dissociation of the tetrameric holoenzyme of E. coli TnaA into the dimeric apoenzyme was accelerated by $\mathrm{K}^{+}$, and that in the absence of the cation the apoenzyme remained tetrameric even at low temperatures. However, Erez et al. (1998) concluded that incubation of the tetrameric form of E. coli TnaA in potassium phosphate buffer at $5{ }^{\circ} \mathrm{C}$ led to the conversion of approximately $24 \%$ of the protein into a dimeric form. Contrary to these conflicting reports, we did not observe dissociation of $P$. gingivalis TnaA into the dimeric form in the presence or absence of $\mathrm{K}^{+}$at $4{ }^{\circ} \mathrm{C}$. The findings suggest that the quaternary structure of TnaA from $P$. gingivalis W83 is more stable in the absence of $\mathrm{K}^{+}$than that from $E$. coli. X-ray crystal structural analyses demonstrated that the tryptophanases from E. coli and Pr. vulgaris contain $\mathrm{K}^{+}$binding sites close to the active site, and that $\mathrm{K}^{+}$ions interact with the $\mathrm{O}^{\varepsilon}$ atom of Glu-72 in one subunit and the backbone carbonyl O atoms of Gly-55 and Pro-275 (Isupov et al., 1998; Ku et al., 2006). P. gingivalis TnaA contained Glu-72 and Gly-55, even though Pro- 275 was replaced by Asn. Structural studies are necessary to understand the stability of $P$. gingivalis TnaA in the presence or absence of $\mathrm{K}^{+}$.

In conclusion, the molecular basis of indole production in $P$. gingivalis was elucidated. Transcripts of $P$. gingivalis tnaA and the encoded protein were characterized. However, the expression mechanism of the gene, which appears to be different in $P$. gingivalis and other bacteria, remains to be elucidated. Further studies of the expression of $P$. gingivalis tnaA are under way to clarify the relationship between indole production and the physiological and pathological functions of this micro-organism.

\section{ACKNOWLEDGEMENTS}

We thank Drs Hasegawa and Yoshimura of Aichi-Gakuin University (Nagoya, Japan) for providing pVA2198. This study was supported in part by Grants-in-Aid for Scientific Research numbers 20592463 and 20592181 and for High-Tech Research Projects (2005-2009) from the Ministry of Education, Culture, Sports, Science and Technology of Japan.

\section{REFERENCES}

Anyanful, A., Dolan-Livengood, J. M., Lewis, T., Sheth, S., Dezalia, M. N., Sherman, M. A., Kalman, L. V., Benian, G. M. \& Kalman, D. (2005). Paralysis and killing of Caenorhabditis elegans by enteropathogenic Escherichia coli requires the bacterial tryptophanase gene. Mol Microbiol 57, 988-1007.

Blankenhorn, D., Phillips, J. \& Slonczewski, J. L. (1999). Acid- and base-induced proteins during aerobic and anaerobic growth of Escherichia coli revealed by two-dimensional gel electrophoresis. J Bacteriol 181, 2209-2216.

Church, G. M. \& Gilbert, W. (1984). Genomic sequencing. Proc Natl Acad Sci U S A 81, 1991-1995.

Claesson, R., Edlund, M. B., Persson, S. \& Carlsson, J. (1990). Production of volatile sulfur compounds by various Fusobacterium species. Oral Microbiol Immunol 5, 137-142.

Deeley, M. C. \& Yanofsky, C. (1981). Nucleotide sequence of the structural gene for tryptophanase of Escherichia coli K-12. J Bacteriol 147, 787-796.

Deeley, M. C. \& Yanofsky, C. (1982). Transcription initiation at the tryptophanase promoter of Escherichia coli K-12. J Bacteriol 151, 942-951. 
Demidkina, T. V., Zakomirdina, L. N., Kulikova, V. V., Dementieva, I. S., Faleev, N. G., Ronda, L., Mozzarelli, A., Gollnick, P. D. \& Phillips, R. S. (2003). Role of aspartate-133 and histidine- 458 in the mechanism of typtophan indole-lyase from Proteus vulgaris. Biochemistry 42, 11161-11169.

Erez, T., Gdalevsky, G., Torchinsky, Y. M., Phillips, R. S. \& Parola, A. H. (1998). Cold inactivation and dissociation into dimers of Escherichia coli tryptophanase and its W330F mutant form. Biochim Biophys Acta 1384, 365-372.

Fosdick, L. S. \& Piez, K. A. (1953). Chemical studies in periodontal disease. X. Paper chromatographic investigation of the putrefaction associated with periodontitis. J Dent Res 32, 87-100.

Garbe, T. R., Kobayashi, M. \& Yukawa, H. (2000). Indole-inducible proteins in bacteria suggest membrane and oxidant toxicity. Arch Microbiol 173, 78-82.

Goldberg, S., Kozlovsky, A., Gordon, D., Gelernter, I., Sintov, A. \& Rosenberg, M. (1994). Cadaverine as a putative component of oral malodor. J Dent Res 73, 1168-1172.

Hansen, M. C., Palmer, R. J., Jr, Udsen, C., White, D. C. \& Molin, S. (2001). Assessment of GFP fluorescence in cells of Streptococcus gordonii under conditions of low $\mathrm{pH}$ and low oxygen concentration. Microbiology 147, 1383-1391.

Hirakawa, H., Inazumi, Y., Masaki, T., Hirata, T. \& Yamaguchi, A. (2005). Indole induces the expression of multidrug exporter genes in Escherichia coli. Mol Microbiol 55, 1113-1126.

Hoch, J. A., Simpson, F. J. \& DeMoss, R. D. (1966). Purification and some properties of tryptophanase from Bacillus alvei. Biochemistry $\mathbf{5}$, 2229-2237.

Honda, T. \& Tokushige, M. (1986). Effects of temperature and monovalent cations on activity and quaternary structure of tryptophanase. J Biochem 100, 679-685.

Horton, R. M., Hunt, H. D., Ho, S. N., Pullen, J. K. \& Pease, L. R. (1989). Engineering hybrid genes without the use of restriction enzymes: gene splicing by overlap extension. Gene 77, 61-68.

Isupov, M. N., Antson, A. A., Dodson, E. J., Dodson, G. G., Dementieva, I. S., Zakomirdina, L. N., Wilson, K. S., Dauter, Z., Lebedev, A. A. \& Harutyunyan, E. H. (1998). Crystal structure of tryptophanase. J Mol Biol 276, 603-623.

Kagamiyama, H., Matsubara, H. \& Snell, E. E. (1972). The chemical structure of tryptophanase from Escherichia coli. 3. Isolation and amino acid sequence of the tryptic peptides. J Biol Chem 247, 15761586.

Kamath, A. V. \& Yanofsky, C. (1992). Characterization of the tryptophanase operon of Proteus vulgaris. Cloning, nucleotide sequence, amino acid homology, and in vitro synthesis of the leader peptide and regulatory analysis. J Biol Chem 267, 19978-19985.

Kawasaki, K., Yokota, A., Oita, S., Kobayashi, C., Yoshikawa, S., Kawamoto, S., Takao, S. \& Tomita, F. (1993). Cloning and characterization of a tryptophanase gene from Enterobacter aerogenes SM-18. J Gen Microbiol 139, 3275-3281.

Kolenbrander, P. E., Andersen, R. N., Blehert, D. S., Egland, P. G., Foster, J. S. \& Palmer, R. J., Jr (2002). Communication among oral bacteria. Microbiol Mol Biol Rev 66, 486-505.

Kostelc, J. G., Preti, G., Zelson, P. R., Tonzetich, J. \& Huggins, G. R. (1981). Volatiles of exogenous origin from the human oral cavity. J Chromatogr 226, 315-323.

Krstulovic, A. M. \& Matzura, C. (1979). Rapid assay for tryptophanase using reversed-phase high-performance liquid chromatography. J Chromatogr 176, 217-224.

Ku, S. Y., Yip, P. \& Howell, P. L. (2006). Structure of Escherichia coli tryptophanase. Acta Crystallogr D Biol Crystallogr 62, 814-823.
Lamont, R. J. \& Jenkinson, H. F. (1998). Life below the gum line: pathogenic mechanisms of Porphyromonas gingivalis. Microbiol Mol Biol Rev 62, 1244-1263.

Lamont, R. J. \& Jenkinson, H. F. (2000). Subgingival colonization by Porphyromonas gingivalis. Oral Microbiol Immunol 15, 341-349.

Lee, J., Jayaraman, A. \& Wood, T. K. (2007). Indole is an inter-species biofilm signal mediated by SdiA. BMC Microbiol 7, 42.

Martin, K., Morlin, G., Smith, A., Nordyke, A., Eisenstark, A. \& Golomb, M. (1998). The tryptophanase gene cluster of Haemophilus influenzae type b: evidence for horizontal gene transfer. J Bacteriol 180, 107-118.

Metzler, C. M., Viswanath, R. \& Metzler, D. E. (1991). Equilibria and absorption spectra of tryptophanase. J Biol Chem 266, 93749381.

Morino, Y. \& Snell, E. E. (1967). The subunit structure of tryptophanase. I. The effect of pyridoxal phosphate on the subunit structure and physical properties of tryptophanase. J Biol Chem 242, 5591-5601.

Morino, Y. \& Snell, E. E. (1970). Tryptophanase (Escherichia coli B). Methods Enzymol 17A, 439-446.

Nakano, Y., Yoshida, Y., Yamashita, Y. \& Koga, T. (1995). Construction of a series of pACYC-derived plasmid vectors. Gene 162, 157-158.

Nakayama, K., Kadowaki, T., Okamoto, K. \& Yamamoto, K. (1995). Construction and characterization of arginine-specific cysteine proteinase (Arg-gingipain)-deficient mutants of Porphyromonas gingivalis. Evidence for significant contribution of Arg-gingipain to virulence. J Biol Chem 270, 23619-23626.

Nelson, K. E., Fleischmann, R. D., DeBoy, R. T., Paulsen, I. T., Fouts, D. E., Eisen, J. A., Daugherty, S. C., Dodson, R. J., Durkin, A. S. \& other authors (2003). Complete genome sequence of the oral pathogenic bacterium Porphyromonas gingivalis strain W83. J Bacteriol 185, 5591-5601.

Newton, W. A., Morino, Y. \& Snell, E. E. (1965). Properties of crystalline tryptophanase. J Biol Chem 240, 1211-1218.

Pace, C. N., Vajdos, F., Fee, L., Grimsley, G. \& Gray, T. (1995). How to measure and predict the molar absorption coefficient of a protein. Protein Sci 4, 2411-2423.

Phillips, R. S. (1987). Reactions of $O$-acyl-L-serines with tryptophanase, tyrosine phenol-lyase, and tryptophan synthase. Arch Biochem Biophys 256, 302-310.

Phillips, R. S. \& Gollnick, P. D. (1989). Evidence that cysteine 298 is in the active site of tryptophan indole-lyase. J Biol Chem 264, 1062710632.

Raibaud, O. \& Goldberg, M. E. (1976). The dissociated tryptophanase subunit is inactive. J Biol Chem 251, 2820-2824.

Rezwan, F., Lan, R. \& Reeves, P. R. (2004). Molecular basis of the indole-negative reaction in Shigella strains: extensive damages to the tna operon by insertion sequences. J Bacteriol 186, 7460-7465.

Snell, E. E. (1975). Tryptophanase: structure, catalytic activities, and mechanism of action. Adv Enzymol Relat Areas Mol Biol 42, 287-333.

Stewart, V. \& Yanofsky, C. (1986). Role of leader peptide synthesis in tryptophanase operon expression in Escherichia coli K-12. J Bacteriol 167, 383-386.

Watanabe, T. \& Snell, E. E. (1977). The interaction of Escherichia coli tryptophanase with various amino and their analogs. Active site mapping. J Biochem 82, 733-745.

Yoshida, Y., Nakano, Y., Amano, A., Yoshimura, M., Fukamachi, H., Oho, T. \& Koga, T. (2002). lcd from Streptoccus anginosus encodes a 
C-S lyase with $\alpha, \beta$-elimination activity that degarades L-cysteine. Microbiology 148, 3961-3970.

Yoshida, Y., Negishi, M. \& Nakano, Y. (2003a). Homocysteine biosynthesis pathways of Streptococcus anginosus. FEMS Microbiol Lett 221, 277-284.

Yoshida, Y., Suzuki, N., Nakano, Y., Shibuya, K., Ogawa, Y. \& Koga, T. (2003b). Distribution of Actinobacillus actinomycetemcomitans serotypes and Porphyromonas gingivalis in Japanese adults. Oral Microbiol Immunol 18, 135-139.
Yoshimura, M., Nakano, Y., Yamashita, Y., Oho, T., Saito, T. \& Koga, T. (2000). Formation of methyl mercaptan from L-methionine by Porphyromonas gingivalis. Infect Immun 68, 6912-6916.

Zakomirdina, L. N., Kulikova, V. V., Gogoleva, O. I., Dementieva, I. S., Faleev, N. G. \& Demidkina, T. V. (2002). Tryptophan indole-lyase from Proteus vulgaris: kinetic and spectral properties. Biochemistry (Mosc) 67, 1189-1196.

Edited by: P. Kolenbrander 